\title{
The impact of vertic soil cracks on submerged macrophyte diaspore bank depth distribution in Mediterranean temporary wetlands
}

\author{
José L. Espinar ， Luis Clemente \\ Joutheast Environmental Research Center (SERC), Florida International University. University Park, Miami, FL 33199, USA \\ Departamento de Geoecología, Instituto de Recursos Naturales y Agrobiología de Sevilla (CSIC), P.O. Box 1052, 41080 Sevilla, Spain
}

\begin{abstract}
In temporary wetlands, a majority of diaspores are located in the upper layers of the soil. In general, it is assumed that the vertical movement of diaspores is caused by animal disturbance, and that reduction in this activity concentrates the diaspores in the topsoil. The occurrence of seasonal cracks and the dispersion of topsoil during dry periods are processes that have been underestimated in diaspore bank studies. Our results indicated that diaspore size can partially explain the density of diaspores of submerged macrophytes observed at four discrete soil depths in Doñana National Park temporary marshes (SW Spain). The top layers of the soil exhibit the largest number of species. Spore density of Riella spp., a liverwort, increases with depth, creating an important reserve of viable diaspores in deep soil. Downward movement of diaspores in soil cracks during dry periods, and the extended longevity of Riella diaspores together explain this inverse depth distribution.
\end{abstract}

Keywords: Chara; Doñana; Riella helicophylla; Polveros; Salinity; Soil dispersion; Seed bank; Spores bank; Secondary dispersal; Liverwort

\section{Introduction}

The depth distribution of seeds and spores (hereafter "diaspores") in the soil has been studied in various ecosystems. Assuming a constant diaspore input into the soil surface, the density of viable diaspores generally decreases with depth, while the age of diaspores generally increases downward in the soil profile (Thompson et al., 1997).

In Mediterranean wetlands permanent diaspore banks are frequent, with a majority of diaspores located in the upper $4 \mathrm{~cm}$, and density decreasing to zero by a depth of $8-12 \mathrm{~cm}$ (Bonis and Lepart, 1994; Grillas et al., 1993; Bonis and Grillas, 2002). In these ecosystems, it is generally assumed that the vertical movement of diaspores in the soil is caused by disturbance by animals (Bonis and Lepart, 1994; Bonis and Grillas, 2002), and reduction in this activity concentrates the diaspores in the upper soil layers of the soil (Bonis and Lepart, 1994).
The relative importance of seasonal soil cracks in redistributing diaspores was described many years ago (Harper, 1977). Bonis and Lepart (1994) observed that soil cracks in Mediterranean wetlands obscure the relationship between age of diaspores and vertical distribution in soil. Espinar et al. (2005) suggested that seasonal soil cracks are an important factor in determining the vertical structure of diaspores bank in temporary wetlands.

In climates with alternating dry and wet seasons, most finetextured soils tend to develop cracks that close during the wet season. Soil with large cracks are called "vertic soils", and experience extreme changes in key soil properties throughout the year (Eswaran et al., 1999). Soil salinity plays an important role in the occurrence of seasonal soil cracks; in clay substrates, it is assumed that soil salinity reduces the energy necessary to cause soil fracture (Nichols and Grismer, 1997; Hallett and Newson, 2005), and thus the occurrence of soil cracks increases with soil salinity. High sodium content in clays is associated with reduced cohesion of surface soils. When particle separation occurs, clay particles expand, causing swelling and soil dispersion. This process increases with soil sodium (Na) content (see Ward and Carter, 2004). During dry periods, the separated clay particles can then move, and the surface of the soil is easily eroded by wind. 
Mediterranean wetlands such as Doñana marshes (SW Spain) display seasonality in flooding period, with a dry season of variable length. Crack formation is frequent and may play an important role in the redistribution of diaspores during dry periods.

Diaspore release by submerged species generally occurs during waterlogged conditions, when soil cracks in the sediment are closed. Diaspores deposited on surface sediment or macrophyte litter at that time can fall into the cracks that form during the dry season. The process of diaspores falling into cracks is a form of secondary dispersal.

In this study, we describe the depth distribution of submerged macrophyte diaspores in the soil. We relate diaspore size, soil salinity, and the depth distribution of the diaspore bank, and discuss the importance of soil cracks in determining how diaspores are distributed within soils.

\section{Methods}

Doñana salt marshes are a non-tidal, temporary marsh with a Mediterranean climate, located in southwest Spain $\left(37^{\circ} \mathrm{N}\right.$, $6^{\circ} \mathrm{W}$ ). During the dry period the study area shows abundant cracks in the soil (as deep as at 0-20 cm; Clemente et al., 1998), covering $15-25 \%$ of the soil surface. In the study area, $\mathrm{NaCl}$ is the dominant salt (Espinar et al., 2002) and wind dispersion of soil is very common during dry seasons. The wind transports clay, silt, submerged macrophyte litter, and fine salt crystal, which together accumulate in some areas to form what are locally named "polveros."

During the early autumn of 2000, six areas within the National Park of Doñana salt marshes were fenced to protect the soil from being mixed by trampling animals. The fenced areas were separated by at least $1 \mathrm{~km}$ and had a surface of $625 \mathrm{~m}^{2}$ each. In October 2002 (before the annual flooding period, and before the season of peak annual germination), 16 soil cores were collected $(0.08 \mathrm{~m}$ diameter and $0.16 \mathrm{~m}$ depth $)$. Each core was sliced into four depth intervals $(0-0.04,0.04-$ $0.08,0.08-0.12$ and $0.12-0.16 \mathrm{~m}$ ), so that a total of 64 samples were obtained. Samples were air dried and carefully homogenized by hand. From each sample, a $0.05 \mathrm{~kg}$ subsample was placed in a $14 \mathrm{~cm}$ petri dish and demineralized water was added until the soil was saturated. The petri dishes were closed to avoid loss of humidity, and stored in the dark at $4{ }^{\circ} \mathrm{C}$ for 30 days to stimulate germination (Baskin and Baskin, 1998). After this period, the samples were sieved to eliminate vegetative propagules, and demineralized water was added to each petri dish until the soil sample was covered (1 cm depth). Loss of water by evaporation was replaced by adding demineralized water in each dish throughout the experiment. The dishes were placed in a germination chamber with a $12 \mathrm{~h} / 12 \mathrm{~h}$ lightdarkness photoperiod, photon flux of $500 \mu \mathrm{mol} \mathrm{m} \mathrm{m}^{-2} \mathrm{~s}^{-1}$, and temperature cycle of $25^{\circ} \mathrm{C} / 15^{\circ} \mathrm{C}$. Every 3 days the number of seedlings in each dish was counted and removed, and the soil was disturbed. After 60 days, the density of seedlings was used to estimated the soil diaspore bank (SB). Salinity $(S)$ of soil samples was estimated by measuring the electrical conductivity (E.C. in $\mathrm{mS} \mathrm{cm}^{-1}$ ) in a 1:5 (w/v) soil:water extract.

We estimated soil bank density using stepwise regression. We used the data we had collected on soil diaspore density at different depths as a dependent variable, soil depth as a categorical predictor (with values of 4, 8, 12, and 16), and diaspore size and soil salinity as continuous predictor variables. Diaspore size in each depth (tSS) were weighted by the abundance of each taxon. Diaspore sizes of Spermatophytae (SS) were obtained from Valdés et al. (1987), sizes of Characeae oospores from Comelles (1985) and Wood and Imahori (1964), and sizes of Riella spp. spores from Cirujano et al. (1988).

In the case of Riella sp., a Duncan's multiple comparison test was employed to asses differences in diaspore bank density among four discrete soil depths.

The data of soil diaspore density were $\log _{10}$-transformed to meet assumptions of normality and homogeneity of variance. Significance was fixed at the 0.05 level throughout the study.

\section{Results}

The top layers of the soil $(0-4 \mathrm{~cm})$ showed the highest number of species, seven. The total diaspore density was approximately 2100 diaspore $\mathrm{m}^{-2}$, and the charophyte species,

Table 1

Diaspore size (length in $\mathrm{m}$; means \pm S.E.) and diaspore abundance (no. diaspore $\mathrm{m}^{-2}$; means \pm S.E.) of taxa present in soil diaspore bank in the temporary marshes of Doñana National Park

\begin{tabular}{|c|c|c|c|c|c|c|c|}
\hline & \multirow{2}{*}{$\begin{array}{l}\text { Diaspore } \\
\text { size }(\mathrm{mm})\end{array}$} & \multicolumn{5}{|l|}{ Diaspore bank } & \multirow[t]{2}{*}{ Frequency } \\
\hline & & $0-0.04 \mathrm{~m}$ & $0.04-0.08 \mathrm{~m}$ & $0.08-0.12 \mathrm{~m}$ & $0.12-0.16 \mathrm{~m}$ & Sum over all depths & \\
\hline Soil salinity & & $2.82 \pm 0.43$ & $3.0 \pm 0.35$ & $3.19 \pm 0.28$ & $3.47 \pm 0.26$ & & \\
\hline Zannichellia obtusifolia & 1.7 & $589 \pm 287$ & $118 \pm 68$ & $52 \pm 52$ & 0 & 759 & 15 \\
\hline Callitriche truncata & 1.5 & $97 \pm 72$ & 0 & 0 & 0 & 97 & 3 \\
\hline Chara spp. & 0.52 & $501 \pm 213$ & $37 \pm 37$ & $193 \pm 193$ & 0 & 731 & 14 \\
\hline Tolypella spp. & 0.365 & $130 \pm 90$ & 0 & 0 & 0 & 130 & 3 \\
\hline Nitella spp. & 0.34 & $16 \pm 16$ & 0 & 0 & 0 & 16 & 1 \\
\hline Lemna minor & 0.2 & $433 \pm 271$ & 0 & $1281 \pm 879$ & $134 \pm 134$ & 1,858 & 10 \\
\hline Riella sp. & 0.095 & $343 \pm 144 \mathrm{a}$ & $2863 \pm 1196 a b$ & $18,632 \pm 10,576 b c$ & $17,629 \pm 5,462 \mathrm{c}$ & 29,453 & 51 \\
\hline Total & & $2110 \pm 588$ & $3019 \pm 122$ & $20,162 \pm 11,344$ & $17,494 \pm 5,460$ & 33,044 & \\
\hline
\end{tabular}

Salinity (soil electric conductivity in $\mathrm{mS} \mathrm{cm}^{-1}$; means \pm S.E.) and frequency (\% occurrence in 72 samples) of each taxon are also shown. Letters (a-c) indicate significant differences (Duncan's $t$-test $P<0.01$ ). 
Table 2

Stepwise multiple regression using $D$ (soil depth), $S$ (soil salinity), tSS (diaspore sizes weighted by it density) as predictor variable, and SB (10 log of total diaspore bank) as a response variable

\begin{tabular}{llllll}
\hline & \multicolumn{2}{l}{ Whole model } & & & Factors \\
\cline { 2 - 3 } \cline { 5 - 6 } & & & & Predictor & $T$ \\
SB & $F$ & $37.12^{2}$ & & $D$ & $4.73 *$ \\
& & & tSS & $6.63 *$ \\
\hline
\end{tabular}

$* P<0.0001$

Zannichellia obtusifolia Talavera, García-Murillo \& Smit, Lemna minor L. and Riella spp. Mont. were the most abundant taxa. The taxa with lowest diaspore densities were Nitella spp. and Callitriche truncata Guss, which were only present in the upper layers of the soil (Table 1).

The number of taxa present in the diaspore bank decreased in deeper samples, and only two species were present at the 12$16 \mathrm{~cm}$ depth. Unlike the other species present in the diaspore bank, the number of Riella spp. spores increased with depth, rising to a very high density at $12-16 \mathrm{~cm}$ depth (about $17,500 \mathrm{~m}^{-2}$; Table 1). Riella spp. is by far the most abundant taxon in the diaspore bank.

The fitted models (Table 2) explain the observed data of total diaspore bank density as a function of soil depth $(D)$ and diaspore size (tSS). Soil salinity $(S)$ does not have a significant effect in the model. The model explains $63 \%$ of the variance in the data $\left(r^{2}=0.63, P<0.0001\right.$; see Table 2$)$.

\section{Discussion}

Generally, the vertical distribution of taxa with large diaspores (C. truncata and Z. obtusifolia) is restricted to the topsoil, while taxa with smaller diaspores (Chara spp., Lemna minor) are more widely distributed in deeper soil, and Riella spp. accumulates at the maximum depths measured.

We suggest that wind plays the principal role in the movement of diaspores on the soil surface during the dry season. The probability of a diaspore moving horizontally across the soil surface must vary inversely with its size, i.e., smaller diaspores are more easily carried away by the wind and are more likely to fall into soil cracks. This process becomes more unlikely as diaspore size increases. Riella spp. have very small diaspores which can easily be removed by the wind and sink in summer soil cracks.

Generally, a decline in diaspore bank density with depth reflects the balance between annual diaspore input from established vegetation and diaspore output by recruitment, predation, or loss of viability. In this study, both the downward movement of diaspores in soil cracks during dry seasons and the extended longevity of Riella diaspores can explain their depth distribution. Riella spp. diaspores have high longevity (up to 13 years sensu Studhalter, 1932), which allows them to accumulate over several years at the bottom of soil cracks (between 15 and $20 \mathrm{~cm}$ depth in the study area, Clemente et al., 1998). At this depth, the diaspore bank is protected from the extremely dry conditions and resulting desiccation that occur during summer, and does not experience significant loss from seasonal recruitment (i.e., germination) or predation.

In our study area, Riella spp. exhibit a persistent diaspore bank, and important reserves of viable spores are present deep in the soil. These diaspores are protected from predation and extreme desiccation in dry periods. For species of conservation importance such as Riella helicophylla, the presence of large numbers of viable spores in deeper soils could serve as "insurance" against local extirpation. The reserve of viable diaspores of Riella spp. therefore may take on special importance in Mediterranean temporary habitats where environmental conditions vary in an unpredictable ways from year to year. In these variable habitats, there are no guarantees of yearly diaspore input into the diaspore bank.

Regarding the management of wetlands, modification of the flooding period from temporary to permanent or semipermanent inundation may also alter diaspore bank structure by modifying the occurrence of seasonal soil cracks.

\section{Acknowledgements}

We thank J.M. Espinar and E. Gutiérrez for field and laboratory assistance, and L.V. García for help with soil salinity data. Thanks to E.A. Middleton and M.S. Ross for the critical review of the manuscript. Financial support comes from the Spanish Ministry of the Environment (MMA, project 05/99).

\section{References}

Baskin, C.C., Baskin, J.M., 1998. Seeds: Ecology, Biogeography, and Evolution of Dormancy and Germination. Academic Press, San Diego.

Bonis, A., Grillas, P., 2002. Deposition, germination and spatio-temporal patterns of charophyte propagule banks: a review. Aquat. Bot. 72, 235248.

Bonis, A., Lepart, J., 1994. Vertical structure of seed banks and the impact of depth of burial on recruitment in two temporary marshes. Vegetatio 112 , 127-139.

Cirujano, S., Montes, C., Martino, P., Enriquez, S., Garcia-Murillo, P., 1988. Contibución al studio del genero Riella Mont. (Sphaerocarpales, Riellaceae) en Espana. Limnetica 4, 41-50.

Clemente, L., Garcia, L.V., Siljeström, P., 1998. Suelos del Parque Nacional de Doñana. Ministerio de Medio Ambiente, Madrid.

Comelles, M., 1985. Clave de identificación de las especies de Carófitos de la Península Ibérica. Claves de identificación de la flora y fauna de las aguas continentales de la Península Ibérica. Asociación Española de Limnología. Publicación $\mathrm{N}^{\circ}$ 1. Ediciones Universidad de Barcelona, Barcelona.

Espinar, J., Garcia, L., García-Murillo, L.V., Toja, P.J., 2002. Submerged macrophyte zonation in a Mediterranean salt marsh: a facilitation effect from established helophytes? J. Veg. Sci. 13, 831-840.

Espinar, J.L., Thompson, K., García, L.V., 2005. Timing of seed dispersal generates a bimodal seed bank. Am. J. Bot. 92, 1759-1763.

Eswaran, H., Beinroth, F.H., Reich, P.F., Quandt, L.A., 1999. Vertisols: Their Properties, Classification, Distribution and Management. US Department of Agriculture, Lincoln, NE, USA.

Grillas, P., García-Murillo, P., Geertz-Hansen, O., Marbá, N., Montes, C., TanHam, L., Grossman, A., 1993. Submerged macrophyte seed bank in a Mediterranean temporary marsh: abundance and relationships with established vegetation. Oecologia 94, 1-6.

Hallett, P.D., Newson, T.A., 2005. Describing soil crack formation using elastic-plastic fracture mechanics. Eur. J. Soil. Sci. 56, 31-38.

Harper, J.L., 1977. The Population Biology of Plants. Academic Press, London. 
Nichols, J.R., Grismer, M.E., 1997. Measurement of fracture mechanics parameters in silty-clay soils. Soil. Sci. 162, 309-322.

Studhalter, R.A., 1932. The elusive ruffle plant, Riella. Sci. Monthly 35, $303-$ 311.

Thompson, K., Bakker, J.P., Beller, R.M., 1997. Soil Seed Banks of North-West Europe: Methodology Density and Longevity. University Press, Cambridge.
Valdés, B., Talavera, S., Fernández Galiano, E., 1987. Flora vascular de Andalucía Occidental. Ketres, Barcelona.

Ward, P.A., Carter, B.J., 2004. Dispersion of saline and non-saline nitric mollisols and alfisols. Soil. Sci. 169, 554-566.

Wood, R.D., Imahori, K., 1964. A Review of the Characeae. Verlag von J. Cramer, Weinheim-New York. 